\title{
Evidence, persuasion and power: Diplomats in international organisations
}

Written by: Aleksander Surdej, Ambassador of Poland to the OECD

Last update: 18 June 2018

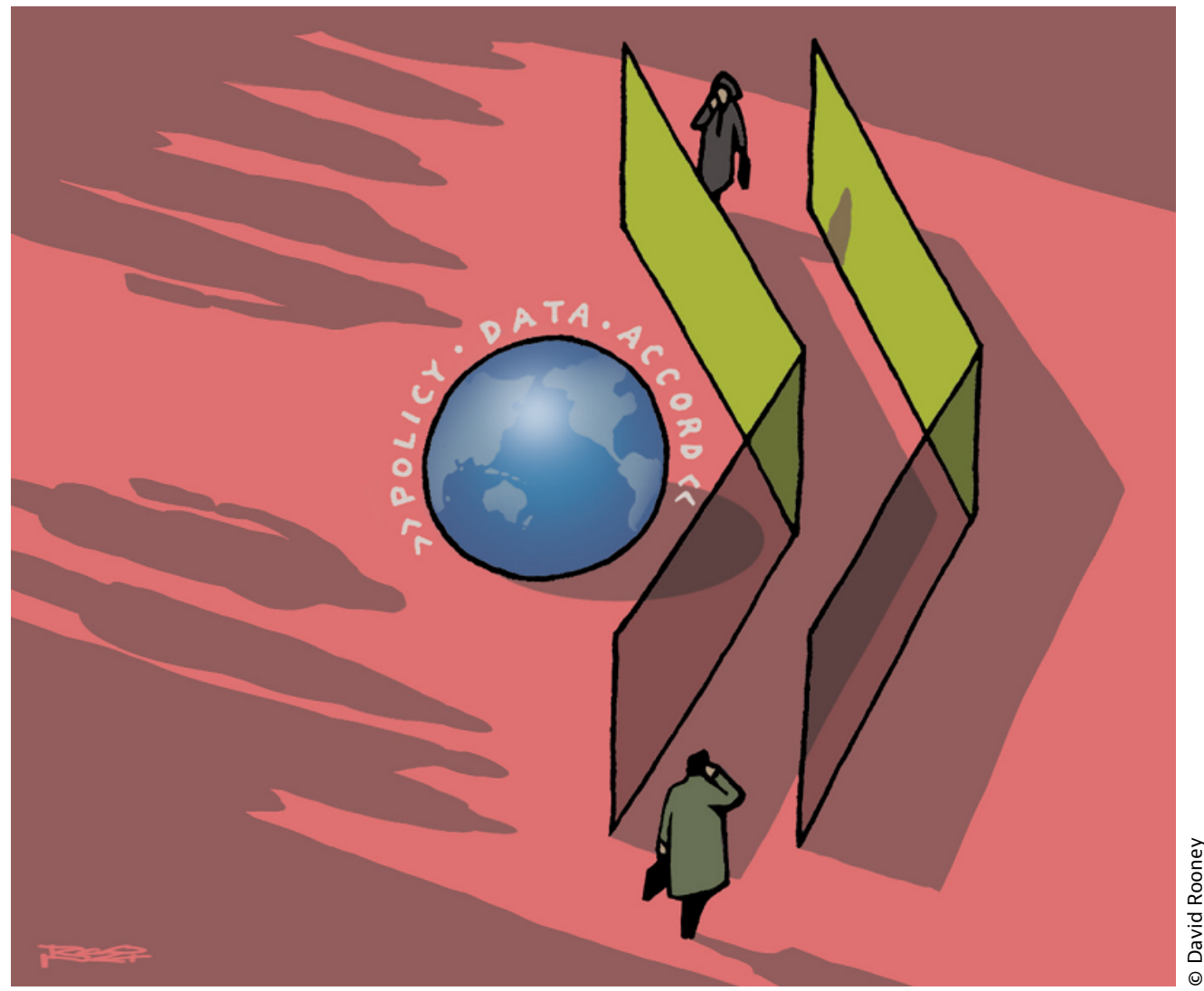

Did you know that each of the OECD's 35 member countries is represented by a mission with full diplomatic status? The size of these OECD delegations varies by country size, but each one has a permanent representative at ambassadorial level, including this author. Together they make up the OECD Council that oversees the work programme set by member countries for the organisation. But our role goes beyond mere representation.

The OECD's experts-those discreet international civil servants who produce data, analysis and insights in great volumes, not to mention guidelines and recommendations on a broad range of government concerns-have an important

1 www.oecdobserver.org | Evidence, persuasion and power: Diplomats in international organisations 
influence on designing, implementing and monitoring public policies, from the global economy, jobs and tax to education, the environment and public governance. Our inputs affect states, corporations and other national, regional and transnational actors.

It should therefore be no surprise that member countries wish to be as involved as possible in influencing the design and likely outcomes of such proposed policies, and they strive to achieve this through their ambassadorial missions. In representing member countries, unlike business and labour stakeholders, we diplomats have the privilege of exerting our influence from within. Still, we must compete for influence, for instance, to maximise the benefits of a proposed reform and minimise the costs, while co-operating in such a way as to preserve the organisation's independence and quality as a precondition to effectively address common problems.

It's a delicate balancing act: new rules and approaches developed by the OECD affect different countries and regions in different ways, yet our growing international interdependence make more common rules and international public policies inevitable (see Scott Barrett, 2007, in the references). This might sometimes mean working to prevent domestic policymaking in one country from damaging the interests of another, for instance in setting new trade restrictions. It could also mean working together to help fight cross-border tax evasion, and other initiatives that many states can benefit from, but that no single country is realistically able to provide on its own.

International co-operation depends on member countries being able to "comanage" this effort, thanks to the daily work of their diplomats. Far from the intrigue of classic James Bond novels, today's diplomats are in fact international public policy analysts, who evaluate and verify information, express opinions based on facts, and seek to win support for particular policy reforms and fight down initiatives they consider to be too costly or ineffective. As a 2016 report on international regulatory co-operation put it, international organisations like the OECD help countries to harmonise technical standards to prevent the confusion and transaction costs stemming from the domestic initiative of individual countries.

Modern-day diplomats can be successful only if their arguments are evidencebased and robust enough to be taken seriously by the experts and fellow member countries. Only then will their efforts help improve the design of international public policy. Their work involves them in a process that requires determination and patience, and an ability to persuade.

A diplomat in international organisations engages in an open and increasingly transparent public process of persuasion, in which the protagonists must be convinced by evidence. An ability to weave a coalition of support is key for driving

2 www.oecdobserver.org | Evidence, persuasion and power: Diplomats in international organisations 
progress, particularly on sensitive issues such as tax or bank transparency, for instance.

Though the OECD's work consists of influencing policymaking and building the general frameworks that underpin the global economy-with rules such as on capital movements, guidelines on multinational enterprises or public sector integrity and much more-it does not generate direct financial benefits or market advantages for anyone. The need for consensus and transparency leaves no scope for lobbyists trying to extract benefits for the few at the expense of the many, or for arranging backdoor deals or making opaque arrangements. Diplomats in this organisation rarely, if ever, find themselves exposed to bribery.

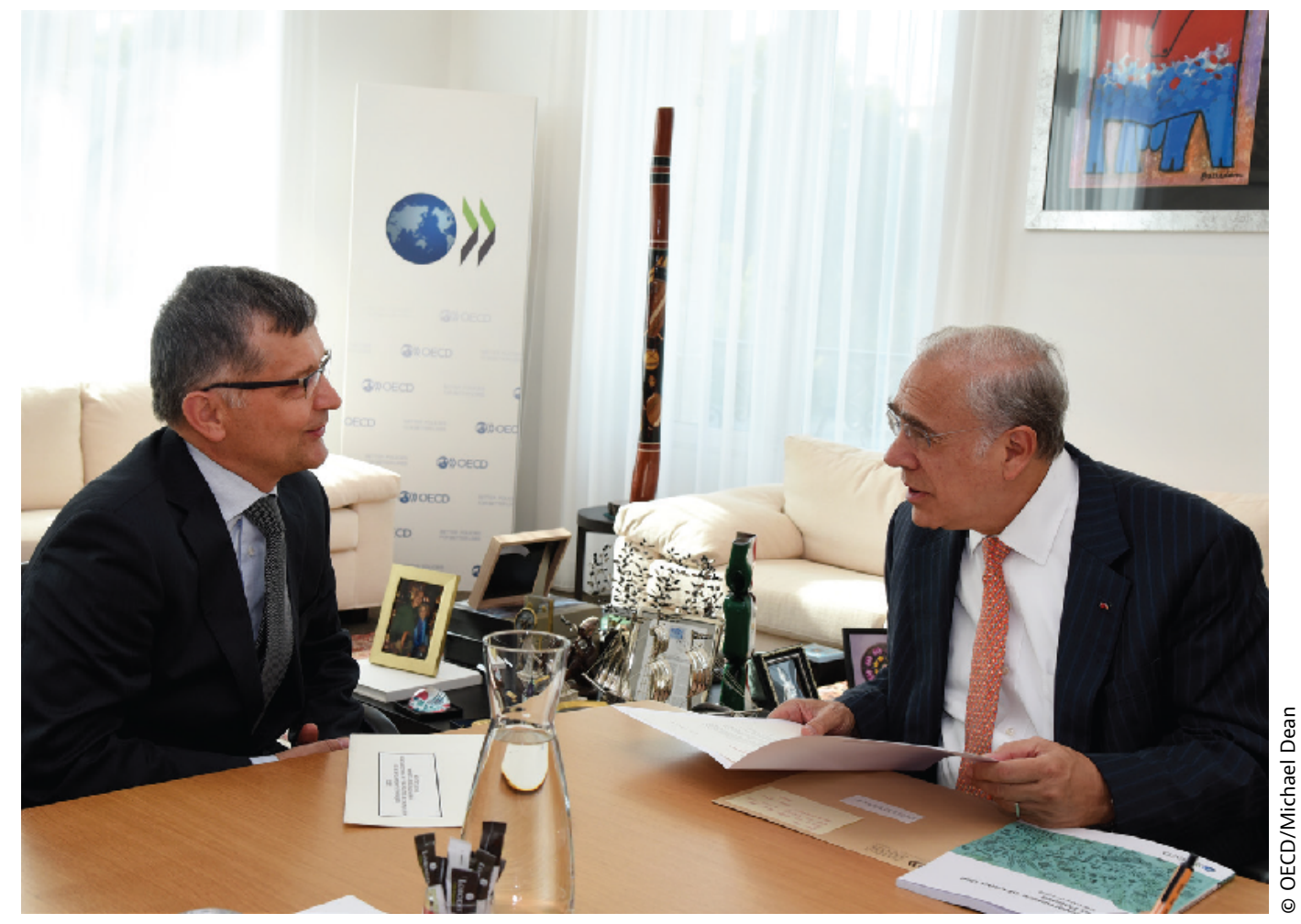

The writer in discussion with OECD Secretary-General Angel Gurría

The effectiveness of a modern diplomat depends on their ability as a policy analyst to participate in all stages of the policymaking cycle. This means not only collecting, elaborating and presenting factbased evidence and arguments, but using the space

the enterprising diplomat can generate real valueadded for international policy provided by international organisations creatively and in an enterprising fashion, by identifying new opportunities, bringing new ideas and products into play, mobilising resources, and forging partnerships. Like all entrepreneurs, we face an uncertain environment. But if done right, the enterprising diplomat can generate real value-added for international policy and set an example for the wider international community. 
The chances of a policy proposal surviving scrutiny at international level depend on having a clear understanding of the structural context in which the policy is forged, and a precise and regularly updated mapping of potential winners and losers.

Consensus-building leads to necessary compromises from the outset. It also means that time is not wasted on unrealistic proposals that everyone knows will lead nowhere. Diplomats become solution-focused facilitators of agreement rather than conveyors of conflict or stubborn defenders of domestic political agendas.

But diplomats must also be key communicators for their compatriots too, as they constantly seek to translate jargon-laden policymaking into a language that their citizens will understand. Being clear about what, why, who, where and when matters greatly for our work, in part so that diplomats and their governments are on the same page as each other regarding a particular reform or programme, and to convincingly explain the importance of multilateral co-operation for making the programme work. This communication helps build and maintain the public's trust at a time when "elites" and "experts" are coming under fire for being out of touch. Diplomats can show the substantial benefits that work carried out in the OECD brings for the many. This means using consistent messaging for all our countries, about the role and value of the organisation, and the quality of its management. In an age of transparency, a diplomat in an international organisation must take on the role of both spokesperson for their country and advocate for the principle of multilateralism as embodied in the OECD.

Share article at http://oe.cd/2c7

\section{References}

The title of this intervention deliberately relates to the title of the classic book by prof. Giandomenico Majone, Evidence, Argument, and Persuasion in the Policy Process, Yale UP, 1989 https://yalebooks.yale.edu/book/9780300052596/ evidence-argument-and-persuasion-policy-process

Barrett, Scott (2007), Why Cooperate?: The Incentive to Supply Global Public Goods, Oxford UP, Oxford https://global.oup.com/academic/product/whycooperate-9780199211890?cc=fr\&lang=en\&

OECD (2016), International Regulatory Co-operation: The Role of International Organisations in Fostering Better Rules of Globalisation, OECD Publishing, Paris http://dx.doi.org/10.1787/9789264244047-en

Stone, Diane (2013), Knowledge Actors and Transnational Governance: The Private-Public Policy Nexus in the Global Agora, Palgrave MacMillan, London https://www.palgrave.com/la/book/9781137022905 